UNIVERSITY OF CHITRAL JOURNAL OF LINGUISTICS AND LITERATURE

VOL. 2 | ISSUE II | JULY - DEC | 2018

ISSN (E): 2663-1512, ISSN (P): 2617-3611

\title{
Relocating Aborigines in Sally Morgan's My Place
}

\author{
Azimullah \\ Assistant Prof, Department of English, Abasyn University of Science and Information \\ Technology, Peshawar \\ Dr. Abdul Hamid \\ Assistant Professor, Department of English, Qurtuba University, Peshawar \\ Syed Hanif Rasool \\ Assistant Professor, Department of English, Khushal Khan Khattak University, Karak
}

\begin{abstract}
Sally Morgan's novel My Place explicitly portrays the resistance of Aborigines subalterns against the prevailing social, economic, cultural and political issues. Focusing on identity, hybridity, ethnicity, and racism, the paper argues how Aborigines undergo social injustice, racial distortion, class disparity and adversarial displacement by Neo-colonialism. Investigating the Aborigines' academic endeavours, genealogical suppressive destitutions, groundbreaking reattachment, matrilineal links, it is hypothesized that My Place foregrounds the contemporary status of modern Aboriginal Woman. Illustrating the Aborigines' altruistic patriotism and excruciating their sufferings during Neo-colonialism in the novel, it is spotlighted how lost generation and stolen generation and extortive afflictions imposed on the Aborigines by the Whites in Australia have shaped the formers' collective socio-cultural and political consciousness.
\end{abstract}

Keywords: Aborigines, colonial projection, subaltern literary resistance, lost generation, stolen generation.

(I)

Sally Morgan's My Place (henceforth called Place), published in 1987, explores colonialism's impacts on Aborigines. Investigating the genealogical and racial links from the angle of sociocultural diversities in the city of Perth, the novel scrutinizes the effects of the first colonization of the Britians on Aborigines. Place accentuates the diverse facades of colonialism. Presenting a transparent compendium of autobiographical narrative, the novel expounds victimological and repudiatory account of colonialism and its impact upon Aborigines' identity. Emphasising Aborigines' exile and exodus, expulsive extortion and excommunication, Sally delineates the historical accounts of white British-Australian colonialism in Australian literature.

Place highlights how matrilineally transmitted cultural knowledge shapes discontentment with diaspora identity which marginalizes Aborigines through stigmatizing their ethnicity and hybridity. Similarly, the double marginalization of women and their self-reconstruction propagate 
via "roots and routes" and "diversity and adversity" (McKenna, 2007). Explicating the distortion, disfigurement, displacement and dissatisfaction of Aborigines, the paper uncovers the truth of genealogy, and living In-Betweens. Sally (the protagonist) recapitulates the rubrics of the narrative. Searching through the pilgrimage journey of 1982 to Corunna Towns, Sally Morgan describes the narrative as "Yet race and racism have created in Place a tension between women as bearers of family history, and women forced to conceal kinship connections or create false genealogy. Curiously, it is Uncle Arthur who provides crucial genealogical information, not Sally's female line." (Morgan, p.149-173); in Perth, Western Australia. These issues are recurrent in the intact narrative. The novel is suffocated with inestimable possibilities in the various implications of Colonial impacts.

\section{(II)}

Colonialism can be defined as "a policy of acquiring or maintaining colonies" especially economic exploitation of weak or backward peoples by a larger power." (The Australian Oxford Dictionary, 2004). These implicational characteristics of power abuse and domination are expressed by Sally. Noticeably, Aborigines encounter numerous sufferings to attain citizenship status. They bear the oppression during Australian colonized era. Aborigines' land occupation by the Whites, subjectivity, and subterfuge in the native country deteriorate their life's cycles. Also, the imperialist expansionism of the territorial powers and the encroachment of the indigenous lands divulge the ethnic factors in a broader spectrum of discrimination such as race, history, religion, language, dress, and scores of other traits.

Simultaneously, Australian indigenous domination and independence concepts have been introduced in the 1901. When the British Parliament passed the bill for Australia colony. This bill is related to the colonies, which controls the colonized under the influence of British confederations. Additionally, the Statue of Westminster is approved by the British Imperial Cabinet, seizing the external affairs of domination from Australia. The bill invested the external diplomatic and other continental affairs domination, policy formulation into the hands of BIC (British Imperial Cabinet) regarding which Sally writes "They just want to live their life free, they don't need the white man's law." (Morgan, p. 236). Deftly, this legislation of colonial power aggravates the Australian strategic policies of native inhabitants either. What the government decides internally is opposed externally by the natives. The diplomatic stagnation, political inconsistencies and lethargic incongruities come to surface drastically in Australia.

\section{(III)}

Britain's colonial power and imperial expansionism drag Australian territories to eurocentrism and ethnocentrism. Colonial maneuvering of the social gaps among Australian natives and its policy of spreading resentment in Aborigines leave indelible marks in the collective historical consciousness of Australia. Sally explores how colonizer's schematizations leave psychological impacts upon the coastal inhabitants to the extent that the original names of latter's native towns were replaced the former's toponyms such as "Botany Bay" for Sidney and so on. (Dunn. et al. 
2001). She highlights how the arrival of the British forces to Botany Bay establishes firmly the expansion of colonial penetrability and pregnancy by means of snatching the native resources in $18^{\text {th }}$ century. Place overwhelms with these acts of penetrations related to the venture of interior Australian territories caused the deterioration and decline of the indigenous communities.

Place further highlights how a large section of Aborigines are caught in the intercommunal conflicts and internal polarities on identity issues, cultural norms, social traits, tribal affairs, and cross-cultural communications. According to Bhatia, (2002), Rieder, (2012), Okazaki, David, \& Abelmann, (2008), such colonial distortions "constitute a form of scientific imperialism, scientific ethnocentrism, or "colonization of the mind". These hegemonic practices morphing into ethnocentric tensions and imperialistic projections sculpt a distorted Aborigines character that John Berry \& Sam, (1997) codify into "Socio-cultural factors such as colonialism, language, and racially discriminating immigration laws. Australian colonial bookish archives report the discussion and current racism scriptures regarding social decay and discrimination". Riggs \& Augoustinos (2005) additionally acknowledge the disintegrative clues in Australia that result from imperial administration as "the ways in which present-day racism in Australia could be understood in context of its colonial history."

(IV)

Place foregrounds socio-cultural and anthropological perspectives of Aborigines by demonstrating their social grievances and humanitarian catastrophes. The former reverse their thoughts and the latter threaten their indispensable growth of individuals. Sally stresses upon the colonizers' forced socio-cultural transformation of the natives and explores how the former portrays her character as an educator of the natives, mellowing the latter's primitive and indigenous cultural traits with a self-acclaimed purpose of the white man 's burden. Place underpins the inhuman and cruel face of colonizers by referring to the stolen generation, i.e. the stealing of children to dislocate their parentage by keeping them in forced confinement for a substantial period so that every memory of their familial relations are wiped of their minds. generation in Australian literature has indicated further clues of adulteration, inflicted upon the Aboriginals as "I always thought of myself as the stolen child." (Morgan, p.404). On the one side suppression by means of official dominance and the other side by misanthropic or anti-humanitarian approach to submerge and suppress the colonized communities. The power expansionism has blitzed the precarious circumstances for world's peace as written in Oxford dictionary "The Aborigines removed from their families as children between the 1900s and the 1960s, to be brought up by white foster families or in institutions." (Concise Oxford Dictionary, 2002).

Next, stolen generation contains attachments with ethno-cultural and ethnic cleansing effects on Aborigines apparently their offspring's trafficking from home territories remonstrate the internal resentments. Seemingly, identity crises revolve around figures of stolen offspring during the last seven decades of Aboriginal colonies. Morgan approaches to such Aboriginal children trafficking as "Off my arm, all I could see was raw meat, the skin had gone. I was all alone and I thought I 
was going to die.” (p. 409). Similarly, the very shenanigan colonial faces of suppression reveal conspicuously their ill-wills so as to deface the locals social and family structures. On the contrary, Aborigines' projections concerning their national consciousness remain fair by their endeavoring for healthy ambience. Aborigines' enhancements in learning and their agricultural skills are evident in in the community, despite the bureaucratic turn-table strategies.

Place predominates the colonizers' instrumentalization through the tool of cultural prostitution, i.e. cultural impurification, socio-political gaps, economic instability and red-trafficking of Aborigines' women, all such injustices proliferate in the Australia's coastal territories. Adulteration spreads in local communities leading a wide gap between national and Aborigines narratives "They might send someone to the house. Government people are like that. Best to say nothing." (p.228). Past analysis of the lexicon date is" according to Merriam Webster's online dictionary dating is "going on a usually romantic encounter" (Webster, 2010). Imperialism culturally and psychologically advocates the reader to analyze the known three-dimensional triangle particularly recounted to the historical, cultural aspects and perspectives of Aboriginals (Sumie, 2008). The discourses about cultural impurification are accentuated by Foster as "Bloody Indians are not Allowed" (Forster, 1924). No doubt, "Attitudes, beliefs, and behaviors that reflect ethnic self-hatred and futile desires to emulate the dominant group at the expense of their heritage culture and ethnicity..." (Varas \& Serrano, 2003).

\section{(V)}

Coherently, the symptoms possessed the ultimate endeavors to dissimilate from inherent dogmas and assimilate with enslavement theories and practices as "Our heritage was not that shared by most Australians, but I hadn't accepted that we were Aboriginal." (Morgan, p.164). Dissimilation and assimilation pre-requisites were the division of collective self-esteem amongst the natives consequently divide and rule cliché application would have probable for colonizers. Bobo and Fox, (2003) "The effects of societal prejudice delineated attitudes towards in-group members among those who are members of the targets of discrimination." Watson, (2007) has stated respecting indigenous women in "Aboriginal Women's Laws and Lives". During colonizing era numerous instances are emerged as Liu and Hilton (2005) have viewed socially shared representation of history as playing a critical role in shaping people's identity." Dissimilarly, Postcolonial theorist Franz Fanon's (1968) writings were influential particularly because of their emphasis on the dehumanizing aspects of colonialism. National unity re/shapes the natives' identity that ameliorates the integrity of people for cohesive society.

Place is the exclusive instance of Aborigines women's reclaiming proclamation of their heritage. Aborigines' endeavors for freedom of thoughts, expression, religion, life, traditional values are expressed. The cultural resources are seized despite of vigorously simultaneous dislocation, distorting disarticulation as "A lot of our history has been lost; people have been too frightened to say anything.” (Morgan. p.271). 
Aborigines' destitution meant of disintegrative unfair treatments in the native land. Aborigines' caste reclamation of their Aboriginal identity of "Lost Generation" is portrayed during instability. (The Australian Oxford Dictionary, 2004). Cultural prostitution are paradigm shift of Sally's narrative as "Men teased me when I bought the farm, they didn't want a black fella movin' in." (Morgan, p.338). similarly, Bhabha represents his views respecting past-present pertinence to human recollections as "a 'new relation to the past' based not on 'resemblance' but on recognition' of our ethical implication in traumatic violence (Bhabha, 2008).

(VI)

Aborigines' displacement, dispossession, disqualification, and discharging have correlational perspectives. The legal and human activities and accentuates upon inflicting profound grief like "First, a policeman came and said, "We've got to sell you up!" (Morgan, 340). By the same token, the inferiority in non-Europeans about their cultural rituals in both metropolitan and nonmetropolitan urbanizations intimidated them. As Frantz Fanon termed it by 'hierarchy of cultures' (Fanon, 1970). Further, Fanon's critical views about intersubjectivity of the colonized in Black Skin White Masks (Fanon, 1952) in which the colonizers are attached with subject and the colonized is termed as object. Explicitly, the lexicons "Other' and 'Not-self". Relatively, Lorde indicates about colonizers' mentality likewise "For the master's tools will never dismantle the master's house." (Lorde, 1981: p.99). Respecting dislocation paragon autobiography of Bermuda's women, who bore into thralldom during Crown colony in 1788c. The putting of hackneyed glace upon her autobiographical narrative represents the slavery of life as "She was sold as an infant, sold again in 1805 as an adolescent, and again as a woman in her twenties. Each time." (Whitlock, 1992). Rustically, Sally expresses her deep concerns about slavery of Aboriginal Blacks in Australia as "Out we had slavery here, too. The people might not have been sold on the blocks like the American Negroes were, but they were owned, Just the same." (Morgan, p. 248). Profoundly, Rotherberg has realized these injunctions as "Colonial expansion created new constellations of histories and temporalities. Such flows constitute and institute memory's 'multidirectionality." (Rothberg, 2009). Mudrooroo comments, about adaptation of colonized stacks as "All cultures and societies change and adapt and it is in a dynamic and shifting environment of adaptation that the political claims of indigenous people are situated." (Mudrooroo,1985). Whereas, colonizers' impositions were holey-solely for manipulative the indigenous mobs of colonized in imperial colonies.

(VII)

Being postcolonial writer, Sally affirms the after-shocks of enslavement of Aborigines in $M y$ Place. White Supremacy has immensely portrayed in the narrative. Even the entire colonial projections and schematization have depicted in more illuminated characterization. The bone of contention is explicitly the colonial machinations and the complexion complexes in Whites revolving and evolving from beginning into the end of the novel. 


\section{UNIVERSITY OF CHITRAL JOURNAL OF LINGUISTICS AND LITERATURE}

You see, the trouble is that colonialism isn't over yet. We still have a White Australia policy against the Aborigines. Aah, it's always been the same. They say there's been no difference between black and white, we all Australian, that's a lie. I tell you, the black man has nothin" the government's been robbin' him blind for years. (Morgan, p.236)

The White Supremacy and discrete dishonesty have been projected predominantly in every colony via dismantlement of the natives. For instance, xenophilia and homophilia bipolarity has been emerged as affirmed by Memmi "The doubleness of the colonized in relation to the colonizer, either as model or antithesis." (Memmi, 1965). In continuation, Aboriginality has authentically harmonized with African-colonialization. Sally's voyages have considered as reconciliatory approaches towards romanticization of predecessors' liaisons and heritage preservations. Gorge, (1996) has affirmed about socio-political narrative of Postcolonial era in "The Politics of Home: Post-colonial Relocation and Twentieth Century Fiction". Correspondingly, such perceptions regarding indigenous national narrative have expounded by Plamenatz in "Nationality' and Nationalism". (Plamenatz, 1973). Additionally, Aborigines have consciously realized their identity and rationalized identity crisis and marginalization as acknowledged by Hooks, \& Gloria, (1989) in 'On Self-Recovery', in Talking Back: Thinking Feminist, Thinking Black".

Aborigines indicated strict adherence to their identity nationality. However, the consanguinity and recuperation of Aborigines' attachment with their disappearing socio-cultural norms; excavation of their dispersed offspring, and lost generation are the living paragons of suffocating propagations of Sally's narrative. Lucidly, linguistic antagonism surfaced either due to the submergence of Aborigines. Aboriginal language speaking had deemed as social backwardness and embarrassment but in My Place Sally has swollen with pride upon the utilization of her language as "Shame! There's mulbas here know their language and won't speak it. I'm not ashamed of my language. I speak it anywhere, even in front of white people." (Morgan, p.360).

\section{Works Cited}

Bhabha, H. K. (2008). "On Global Memory: Thoughts on the Barbaric Transmission of Culture" Lecture given at the Townsend Center for the Humanities, University of California, Berkeley, $\quad 14 \quad$ April 2008.20 source:<http://www.youtube.com/watch?v=5Fp6j90zpn4>, accessed18th Dec, 2012.

Bhatia, S., \& Ram, A. (2001). Rethinking 'acculturation' in relation to diasporic cultures and postcolonial identities. Human Development, 44, 1-18.

Bobo, L. D., \& Fox, C. (2003). Race, racism, and discrimination: Bridging problems, methods, and theory in social psychological research. Social Psychology Quarterly, 66, 319-332.

Concise Oxford Dictionary. (2002), $11^{\text {th }}$ ed. Oxford University Press 
Dunn, K. M., Gandhi, V., Burnley, I., \& Forrest, J. (2003). Racism in Australia: Cultural imperialism, disempowerment and violence. In J. Gao, R. Le Heron \& J. Logie (Eds.), Windows on a changing world: Proceedings of the 22nd New Zealand Geographical Society Conference, New Zealand Geographical Society Conference Series No. 22, New Zealand Geographical Society (Inc.), pp. 175-79.

Fanon, F. (1952). 'The Fact of Blackness' in Black Skin, White Masks (Peaunoire, masques blancs, Paris: Seuil), trans. Charles Lam Markmann (1968), London: MacGibbon and Kee.

Fanon, F. (1968 [1961]). The Wretched of the Earth, trans. Constance Farrington. New York: Grove

. (1970b). Toward the African Revolution, trans. Haakon Chevalier, Harmondsworth: Penguin.

Forster, M. E. (1924). A Passage to India. London. Cambridge Press

Gorge. M. (1996). The Politics of Home: Post-colonial Relocation and Twentieth Century Fiction: Cambridge University Press.

Hooks, B. \& Gloria, W. (1989). 'On Self-Recovery', in Talking Back: Thinking Feminist, Thinking Black, Boston: South End Press.

Jones, J. (1997). Prejudice and racism (2nd Ed.). New York: McGraw-Hill.

Liu, J. H., \& Hilton, D. J. (2005). How the past weighs on the present: Social representations of history and their role in identity politics. British Journal of Social Psychology, 44, 1-12.

Lorde, A. (1981). 'The Master's Tools Will Never Dismantle the Master's House', in Cherrie Moraga and Gloria Anzaldúa (eds) (1983) This Bridge Called My Back: Writings by Radical Women of Color, Latham, NY: Kitchen Table Press.

McKenna, M 2007, 'Damaged Generation', The Australian 22 June, p.13.

Memmi, A., (1965). The Colonizer and the Colonized, New York: Orion.

Morgan, S. (1987). My Place. Fremantle: Fremantle Arts Centre Press

Morgan, S. (2002). Echoes of the past: Sister Kate's home revisited. Perth: Centre for Indigenous History and the Arts, University of Western Australia.

Mudrooroo, (1985). 'White Forms, Aboriginal Content', in Jack Davis and Bob Hodge (eds) Aboriginal Writing Today: Papers from The First National Conference of Aboriginal Writers Held in Perth, Western Australia 1983, Canberra: Australian Institute of Aboriginal Studies.

Okazaki, S., David, E. J. R., \& Abelmann, N. (2008). Colonialism and psychology of culture. Social and personality psychology compass, 2(1), 90-106. 
Plamenatz, J. (1973). 'Two Types of Nationalism', in E. Kamenka (ed.) Nationalism: The Nature and Evolution of an Idea, Canberra: Australian National University Press.

Rieder, J. (2012). Colonialism and the emergence of science fiction. Wesleyan University Press.

Riggs, D., \& Augoustinos, M. (2005). The psychic life of colonial power: Racialised subjectivities, bodies and methods. Journal of Community \& Applied Social Psychology, 15, 461-477.

Rothberg, M. (2009). Multidirectional Memory: Remembering the Holocaust in the Age of Decolonization. Stanford: Stanford University Press.

Sumie, O. 1. E. (2008, Jan). Colonialism and Psychology of culture, Social and Personality Psychology Campass, Retrieved on $12^{\text {th }}$ June 2016 from www.Journal Compilation. com.

The Australian Oxford Dictionary. (2004) 2nd Edition; Oxford University Press

Varas-Diaz, N., \& Serrano-Garcia, I. (2003). The challenge of a positive self-image in a colonial context: A psychology of liberation for the Puerto Rican experience. American Journal of Community Psychology, 31, 103-115.

Watson, I. 2007, 'Aboriginal Women's Laws and Lives: How Might We Keep Growing the Law? Australian Feminist Law Journal 26, p. 95-107.

Webster, M. (2010, May 17). Merriam Webster's Online Dictionary. Retrieved May 17, 2010, from Merriam Webster Online: http://www.merriamwebster.com/dictionary/courting

Whitlock, G. (1992). "Outlaws of the Text: Women's Bodies and the Organisation of Gender in Imperial Space", Paper presented at "Australia/ Canada Post-colonialization and Women's Texts' Conference, Research Network, Calgary Institute for the Humanities (February 1316)

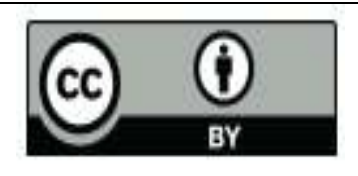

@ 2017 by the author. Licensee University of Chitral, Journal of Linguistics \& Literature, Pakistan. This article is an open access article distributed under the terms and conditions of the Creative Commons Attribution (CC BY) (http://creativecommons.org/licenses/by/4.0/). 